\title{
In Vitro Toxicity Evaluation of Engineered Cadmium-Coated Silica Nanoparticles on Human Pulmonary Cells
}

\author{
Uliana De Simone, ${ }^{1}$ Luigi Manzo, ${ }^{1,2}$ Antonella Profumo, ${ }^{3}$ and Teresa Coccini ${ }^{2}$ \\ ${ }^{1}$ Department of Clinical-Surgical, Diagnostic and Pediatric Sciences, University of Pavia, 27100 Pavia, Italy \\ ${ }^{2}$ Laboratory of Clinical Toxicology, IRCCS Maugeri Foundation, Medical Institute of Pavia, 27100 Pavia, Italy \\ ${ }^{3}$ Department of Chemistry, University of Pavia, 27100 Pavia, Italy
}

Correspondence should be addressed to Teresa Coccini; teresa.coccini@fsm.it

Received 29 July 2013; Accepted 26 August 2013

Academic Editor: Michael Cunningham

Copyright (C) 2013 Uliana De Simone et al. This is an open access article distributed under the Creative Commons Attribution License, which permits unrestricted use, distribution, and reproduction in any medium, provided the original work is properly cited.

\begin{abstract}
Cytotoxicity of cadmium-containing silica nanoparticles $\mathrm{Cd}-\mathrm{SiO}_{2} \mathrm{NPs}(0.05-100 \mu \mathrm{g} / \mathrm{mL})$ versus $\mathrm{SiO}_{2} \mathrm{NPs}$ and $\mathrm{CdCl}_{2}$ was evaluated by an in vitro test battery in A549 by assessing (i) mitochondrial function, (ii) membrane integrity/cell morphology, (iii) cell growth/proliferation, (iv) apoptotic pathway, (v) oxidative stress, after short- (24-48 h) and long-term (10 days) exposure. Both Cd$\mathrm{SiO}_{2} \mathrm{NPs}$ and $\mathrm{CdCl}_{2}$ produced dose-dependent cytotoxic effects: (i) MTT-assay: similar cytotoxicity pattern was observed at both 24 and $48 \mathrm{~h}$, with a more $\mathrm{Cd}-\mathrm{SiO}_{2} \mathrm{NPs}$ pronounced effect than $\mathrm{CdCl}_{2}$. Cd-SiO $\mathrm{NPs}_{2}$ induced mortality (about $50 \%$ ) at $1 \mu \mathrm{g} / \mathrm{mL}, \mathrm{CdCl}$ at $25 \mu \mathrm{g} / \mathrm{mL}$; (ii) calcein-AM/PI staining: decrease in cell viability, noticeable at $25 \mu \mathrm{g} / \mathrm{mL}$, enhanced markedly at 50 and $100 \mu \mathrm{g} / \mathrm{mL}$, after $24 \mathrm{~h}$. Cd-SiO 2 NPs induced higher mortality than $\mathrm{CdCl}_{2}$ (25\% versus $4 \%$, resp., at $25 \mu \mathrm{g} / \mathrm{mL}$ ) with further exacerbation after 48h; (iii) clonogenic assay: exposure for longer period (10 days) compromised the A549 proliferative capacity at very low dose $(0.05 \mu \mathrm{g} / \mathrm{mL})$; (iv) a progressive activation of caspase-3 immunolabelling was detected already at $1 \mu \mathrm{g} / \mathrm{mL}$; (v) GSH intracellular level was modified by all compounds. In summary, in vitro data demonstrated that both $\mathrm{Cd}-\mathrm{SiO}_{2} \mathrm{NPs}_{\text {and }} \mathrm{CdCl}_{2}$ affected all investigated endpoints, more markedly after $\mathrm{Cd}-\mathrm{SiO}_{2} \mathrm{NPs}$, while $\mathrm{SiO}_{2} \mathrm{NPs}$ influenced GSH only.
\end{abstract}

\section{Introduction}

The rapid development of nanotechnology worldwide is accompanied by massive generation and usage of engineered nanoparticles (ENPs), even though essentially most of these NPs have not been sufficiently examined for potential toxicity at this time $[1,2]$. Thus, with the exponential growing production of ENPs, the potential for the respiratory system to be exposed to a seemingly countless number of unique NPs is expected to increase, and many aspects related to the size of these nanomaterials, smaller than cells and cellular organelles, have raised concerns about safety [2-4].

Among ENPs, silica/cadmium containing nanomaterials have attracted much attention in the latest years for their applications in medicine and industrial manufacturing, synthesis, and engineering [5-10]. Though silica nanoparticles
$\left(\mathrm{SiO}_{2} \mathrm{NPs}\right)$ are generally considered to be nontoxic, experiments using cell cultures or animal models have indicated dose-dependent cytotoxicity, increased reactive oxygen species, and reversible lung inflammation [11-19]. On the other hand, a large body of evidence supports lung toxicity effects after cadmium exposure when inhaled [20,21], and although its toxicity mechanisms are not yet fully understood, several reports have described pulmonary inflammatory changes and induction of oxidative stress in response to cadmium inhalation exposure [22].

Some NPs, such as metal-based nanomaterials should represent risk factors for lung diseases, as many of these metals in their native form are known to have fibrogenic, inflammogenic or carcinogenic effects in humans. Evaluation of the NPs biosafety is essentially required by tests examining general toxicity, target organ toxicity, and biocompatibility in 
line with regulatory requirements and to identify molecular endpoints and multiple toxicity pathways.

The present study intended to elucidate the toxicological profile of a model nanomaterial namely cadmium-containing silica nanoparticles ( $\left.\mathrm{Cd}-\mathrm{SiO}_{2} \mathrm{NPs}\right)$ by an in vitro testing approach.

For instance, a key concept, developed from the strategy proposed by major institutions $[23,24]$ and international consensus meetings [25], indicates the use of multi-tiered testing protocols to address toxicological research and health risk assessment for NPs, based on (i) physic-chemical characterization, (ii) in vitro models by a battery of cytotoxicity tests, and (iii) in vivo experiments driven on the basis of the in vitro results. Information generated using in vivo studies will also provide a database from which to compare in vitro studies for identifying additional evidence that assists in explaining findings from in vivo nanomaterial toxicity or health effects. Comparing the in vitro and in vivo results may also help to assess the concordance/discordance between the alternative methods and the in vivo methods, and to test the predictability of the alternative methods for the in vivo results [26].

The identification of predictive in vitro toxicity assays is in line with the recommended attention that should be given to regulatory acceptance as means of promoting the use of alternative methods to animal testing in human safety assessment $[27,28]$.

Our recent in vivo investigation on $\mathrm{Cd}-\mathrm{SiO}_{2} \mathrm{NPs}$ indicated long-lasting lung damage, after intratracheal instillation (i.t.) of these nanoparticles in rats, characterized by morphological alterations, the occurrence of inflammation (accompanied by granuloma formation), stromal fibrogenic reaction, and enhancement of apoptotic phenomena followed by a consequent increased cell proliferation [29]. This pulmonary insult was also associated with an oxidative stress response [30].

In this work, a battery of in vitro tests have been used to examine the responses of human lung epithelial cells to $\mathrm{Cd}-\mathrm{SiO}_{2} \mathrm{NPs}$ exposure in terms of metabolic activity (by MTT assay), membrane integrity (by calcein-AM/Propidium Iodide staining), oxidative stress (by GSH content evaluation), apoptosis (by activated caspase- 3 evaluation), and growth and cell proliferation (by clonogenic assay) to determine whether the modification of morphological and biochemical parameters evaluated by in vitro investigations are in accordance with in vivo pulmonary insult caused by these nanoparticles. The effects of $\mathrm{Cd}-\mathrm{SiO}_{2} \mathrm{NPs}$ were assessed in A549 cell line, which represents a widely used cell model to investigate alveolar cell function [31], after short- (24-48 hours) and long-term (10 days) exposure and compared with those caused by treatments with cadmium chloride $\left(\mathrm{CdCl}_{2}\right)$ and $\mathrm{SiO}_{2} \mathrm{NPs}$.

\section{Materials and Methods}

2.1. Chemicals. All cell culture reagents, chemicals, and cadmium chloride hemi (pentahydrate; $\mathrm{CdCl}_{2}$ ) were obtained from Sigma-Aldrich (Milan, Italy). Caspase 3 and Alexa 488labeled antibodies from Molecular Probes (Life Technologies, Monza, Italy) and the GSH quantification Kit from Oxis
International Inc. (Foster City, Ca, USA). Silica nanosize $\left(\mathrm{SiO}_{2} \mathrm{NP}\right)$ was purchased from Degussa Gmbh (Germany) as HiSilTM T700, average pore size $20 \mathrm{~nm}$, surface area $240 \mathrm{~m}^{2} / \mathrm{g}$, and pore specific volume of $0.4 \mathrm{~cm}^{3} / \mathrm{g}$.

2.2. Synthesis and Physico-Chemical Characterization of Engineered Cadmium-Coating Nanoparticles (Cd-SiO ${ }_{2} \mathrm{NPs}$ ). Synthesis and physico-chemical characterization of Cd-SiNPs are previously described in Coccini et al. [29]. Briefly, Cd$\mathrm{SiO}_{2} \mathrm{NPs}$ were produced by the impregnation of $\mathrm{SiO}_{2} \mathrm{NPs}$ with cadmium nitrate dehydrate $\left(\mathrm{CdNO}_{3} 3.56 \times 10^{-2} \mathrm{M}\right)$ in an aqueous solution with silica dispersed in a concentration ratio leading to a sample containing $40 \% \mathrm{Cd}$ by weight. Powder was later subjected to grinding mills with high energy ( $200 \mathrm{rpm}$ for $1.5 \mathrm{~h}, 400 \mathrm{rpm}$ for $1.5 \mathrm{~h}, 600 \mathrm{rpm}$ for $2 \mathrm{~h}$ ) to get the most equal distribution of particle size and/or aggregates of particles. The entire synthesis preparation was performed under sterile condition to avoid NPs contamination.

Quantitative analyses by scanning transmission electron microscopy (STEM) showed the aggregation of $\mathrm{Cd}-\mathrm{SiO}_{2} \mathrm{NPs}$ and the analysis of the elements in High Angle Annular Dark Field (HAADF) mode (energy-dispersive (EDS) spectra) confirmed the presence of $\mathrm{Cd}, \mathrm{Si}$, and $\mathrm{O}$. X-ray diffraction demonstrated amorphous and crystalline phases of the sample. Dynamic light scattering (DLS) of the $\mathrm{Cd}-\mathrm{SiO}_{2} \mathrm{NPs}$ showed tendency to form aggregates and agglomerates of about $350 \mathrm{~nm}$ (zeta potential about $-23 \mathrm{mV}$ in DMEM). Particles presented spherical form, primary particle size range of 20-80 $\mathrm{nm}$ and specific surface area of about $200 \mathrm{~m}^{2} / \mathrm{g}$. Metal impurities (Ca (0.3\%), Na (0.2\%), K (0.2\%), Fe (0.04\%), and $\mathrm{Mn}(0.001 \%))$ and the release of cadmium from nanoparticles dispersed in culture medium were determined by flameatomic absorption analysis. Maximum cadmium release in culture medium (DMEM) was $28 \%$ after $16 \mathrm{~h}$, and it was negligible in the subsequent 10 -day period.

2.3. Cell Line and Cell Culture. Human lung epithelial cells (A549 cell line purchased from ECACC, Sigma-Aldrich, Milan, Italy) were used for in vitro study of the nanoparticle toxicity. Cells were cultured in DMEM supplemented with $10 \%$ fetal bovine serum (FBS), $2 \mathrm{mM} \mathrm{L}$-glutamine, $50 \mathrm{IU} / \mathrm{mL}$ penicillin, and $50 \mu \mathrm{g} / \mathrm{mL}$ streptomycin. Cells were maintained at $37^{\circ} \mathrm{C}$ in a humidified atmosphere (95\% air/5\% $\left.\mathrm{CO}_{2}\right)$.

Stock solutions were prepared by dissolving test materials (Cd-SiO $\mathrm{CP}_{2} \mathrm{NP}, \mathrm{CdCl}_{2}$, and $\mathrm{SiO}_{2} \mathrm{NPs}$ ) in culture medium (DMEM), then cells were exposed to concentrations ranging from 0.05 to $100 \mu \mathrm{g} / \mathrm{mL}$. Fresh solutions of test materials were prepared shortly before each experiment.

Doses were chosen based on previous experiments in A549 cells showing toxic effects (e.g., apoptosis, necrosis) after cell exposure to concentrations ranging from 5 to $60 \mu \mathrm{M}$ (corresponding: 0.916 to $10.99 \mu \mathrm{g} / \mathrm{mL}$ ) of $\mathrm{CdCl}_{2}$ [32-35].

\subsection{Cytotoxicity Study: Short-Term Exposure (24-48 h)}

2.4.1. Mitochondrial Function (MTT Assay) and Membrane Integrity (Calcein-AM/Propidium Iodide Staining). The viability was assessed by two dye-based methods: MTT assay (mitochondrial function) and calcein-AM/Propidium Iodide 
(PI) staining (membrane integrity). Cells were seeded in 96well plates at density of $1 \times 10^{4}$ cells/well in complete medium. After $24 \mathrm{~h}$ of cell attachment, the cells were exposed to $\mathrm{Cd}$ $\mathrm{SiO}_{2} \mathrm{NPs}$ at final concentration of Cd between 1 to $100 \mu \mathrm{g} / \mathrm{mL}$ for 24 or $48 \mathrm{~h}$ at $37^{\circ} \mathrm{C}$ and compared to equivalent amount of $\mathrm{CdCl}_{2}$ or $\mathrm{SiO}_{2} \mathrm{NPs}$.

At the end of the incubation period, the mitochondrial function was assessed by $0.5 \mathrm{mg} / \mathrm{mL}$ MTT (3-(4,5-dimethylthiazol-2-yl)-2,5-diphenyltetrazolium bromide) for $3 \mathrm{~h}$ at $37^{\circ} \mathrm{C}$ and was quantified spectrophotometrically at $550 \mathrm{~nm}$ in Biorad microplate reader. Data were expressed as a percentage of control (untreated cells).

The membrane integrity was evaluated by the coincubation of the double staining: $2 \mu \mathrm{M}$ calcein-AM and $2.5 \mu \mathrm{g} / \mathrm{mL}$ PI for $5 \mathrm{~min}$ at $37^{\circ} \mathrm{C}$. Cells were examined under a Zeiss Axiovert 25 fluorescence microscope combined with a digital camera (Canon powershot G8). The fluorescence images were taken using 32x objective lens with an excitation wavelength of $400,495,570 \mathrm{~nm}$; beamsplitter wavelength of $410,505,585 \mathrm{~nm}$; and an emission wavelength of 460 , $530,610 \mathrm{~nm}$. Viability was expressed as percent cells retained calcein compared to the total cells counted (calcein-positive plus PI-positive).

2.4.2. Oxidative Stress Evaluation: Glutathione (GSH) Measurement. The concentration of intracellular GSH was determined by colorimetric assay. Briefly, cells were seeded in six-well plates at density of $5 \times 10^{5}$ cells/well. After the treatments with $2 \mathrm{~mL}$ of $\mathrm{Cd}-\mathrm{SiO}_{2} \mathrm{NPs}, \mathrm{CdCl}_{2}$ and $\mathrm{SiO}_{2} \mathrm{NPs}$ (final concentration ranging from 1 to $100 \mu \mathrm{g} / \mathrm{mL}$ in cell culture medium) for 24 and $48 \mathrm{~h}$ exposure, the medium was aspired and the cells was washed once with phosphate buffer saline (PBS). Then, the cells were scraped and centrifuged at $1100 \mathrm{rpm}$ for $3 \mathrm{~min}$ at $25^{\circ} \mathrm{C}$, the superrnatant was removed by aspiration. The cell pellets were resuspended in ice-cold metaphosphoric acid (MPA) and immediately homogenized (Ultra Turrax, Janke \& Kunkel) then centrifuged at $3000 \mathrm{~g}$, $4^{\circ} \mathrm{C}$ for $10 \mathrm{~min}$. Subsequently, the samples were mixed with 4 Chloro-1-Methyl-7-Trifluromethyl-Quinolinium Methylsulfate and $30 \%$ sodium hydroxide reagents, and then were incubated for $10 \mathrm{~min}$ at room temperature (r.t.) in dark. The absorbance was measured spectrophotometrically (Spectrometer Lambda Bio 20, Perkin Elmer) at $400 \mathrm{~nm}$, total glutathione content was determined with a standard curve.

2.4.3. Apoptotic Pathway: Immunofluorescence Detection of Activated Caspase 3. Cells were seeded in coverslips at density of $2 \times 10^{5}$ cells. After 24 -h cell attachment, the cells were exposed to increasing concentrations of Cd- $\mathrm{SiO}_{2} \mathrm{NPs}, \mathrm{CdCl}_{2}$, and $\mathrm{SiO}_{2} \mathrm{NPs}(1-50 \mu \mathrm{g} / \mathrm{mL})$ for $24 \mathrm{~h}$ at $37^{\circ} \mathrm{C}$. At the end of incubation period, the cells were fixed with $4 \%$ paraformaldehyde for $20 \mathrm{~min}$ at r.t. and then in $70 \%$ ethanol over night at $-20^{\circ} \mathrm{C}$. After rehydration with PBS, the samples were incubated with blocking solution for $30 \mathrm{~min}$ at r.t., and then with polyclonal antibodies recognizing caspase 3 (dilution $1: 200$ in PBS). After washing, the bound antibodies were revealed with Alexa 488-labeled (dilution 1:100 in PBS) antibody recognizing rabbit-Ig. The slides were counterstained for DNA with $1 \mu \mathrm{g} / \mathrm{mL}$ Propidium Iodide, washed with PBS and finally mounted with Fluoroshield. Cells were examined under a CX41 Olympus fluorescence microscope, excitation light being provided by EPI LED Cassette (FRAEN, Settimo Milanese (MI), Italy) and combined with digital camera (Infinity2). Digital images were captured using 100x objective lens, measurement conditions were: $470 \mathrm{~nm}$ excitation ( $T \%=$ 40), $505 \mathrm{~nm}$ dichroic beamsplitter, $510 \mathrm{~nm}$ long pass filter.

\subsection{Cytotoxicity Study: Long-Term Exposure (10 Days)}

2.5.1. Clonogenic Assay. The procedure for clonogenic assay was adopted from Herzog et al. [36]. A549 cells were seeded in six-well at density of 400 cells/well, each well containing $2 \mathrm{~mL}$ of cell culture medium. After attachment (about $14 \mathrm{~h}$, time was shorter than the population doubling time), the cells were washed with $2 \mathrm{~mL}$ PBS, and treated with $2 \mathrm{~mL}$ of Cd$\mathrm{SiO}_{2} \mathrm{NPs}, \mathrm{CdCl}_{2}$, and $\mathrm{SiO}_{2} \mathrm{NPs}$ (final concentration ranging from 0.05 to $100 \mu \mathrm{g} / \mathrm{mL}$ in cell culture medium) over a time period required to form colonies (about 10 days). A colony being defined as at least 50 clones of one cell. At the end of the treatment, the medium was removed and the colonies were fixed, stained with Hematoxylin and then counted for the evaluation of cell survival after $\mathrm{Cd}-\mathrm{SiO}_{2} \mathrm{NP}, \mathrm{CdCl}_{2}$ and $\mathrm{SiO}_{2} \mathrm{NP}$ treatments. The colonies were examined under Zeiss Axiovert 25 microscope combined with a digital camera (Canon powershot G8).

Digital photographs were taken from each well using $2.5 \mathrm{x}$ objective lens. The number of colonies that arose after treatment (surviving fraction) was expressed in terms of plating efficiency (PE). PE was calculated by dividing the number of colonies formed by the number of cells plated per 100.

2.6. Statistics. Data from acute exposure were obtained from three independent experiments each carried out in six replicates. Data from chronic exposure were obtained from two independent experiments and each experiment was carried out in three replicates. Results are expressed as mean \pm SD. Statistical significance was assessed by one-way ANOVA. A value of $P<0.05$ was considered statistically significant.

\section{Results}

3.1. Cytotoxic Activity of $\mathrm{Cd}-\mathrm{SiO}_{2} \mathrm{NPs}$ Compared to $\mathrm{CdCl}_{2}$ and $\mathrm{SiO}_{2} \mathrm{NPs}$ in $\mathrm{A} 549$ Cell Line. In vitro cytotoxicity results after short- (24-48h) and long-term (10 days) exposure of A549 cells to increasing concentrations of $\mathrm{Cd}-\mathrm{SiO}_{2} \mathrm{NPs}$, $\mathrm{CdCl}_{2}$, and $\mathrm{SiO}_{2} \mathrm{NPs}$ (from 0.05 to $100 \mu \mathrm{g} / \mathrm{mL}$ ) are reported and compared. Mitochondrial function, membrane integrity, oxidative stress, apoptosis were considered as endpoints of acute exposure, while the capacity to form colonies was considered as endpoint of chronic exposure.

\subsection{Cytotoxicity Results after Short-Term Exposure (24-48 h)}

3.2.1. Mitochondrial Function: MTT Assay. Data of mitochondrial function, evaluated by MTT after 24 and $48 \mathrm{~h}$ of exposure to increasing concentrations of $\mathrm{Cd}-\mathrm{SiO}_{2} \mathrm{NPs}$, 


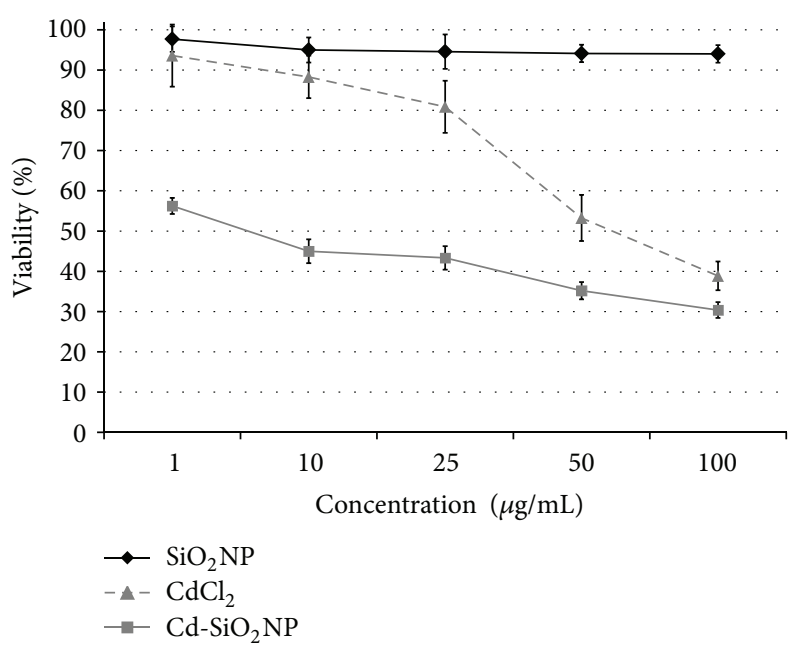

(a)

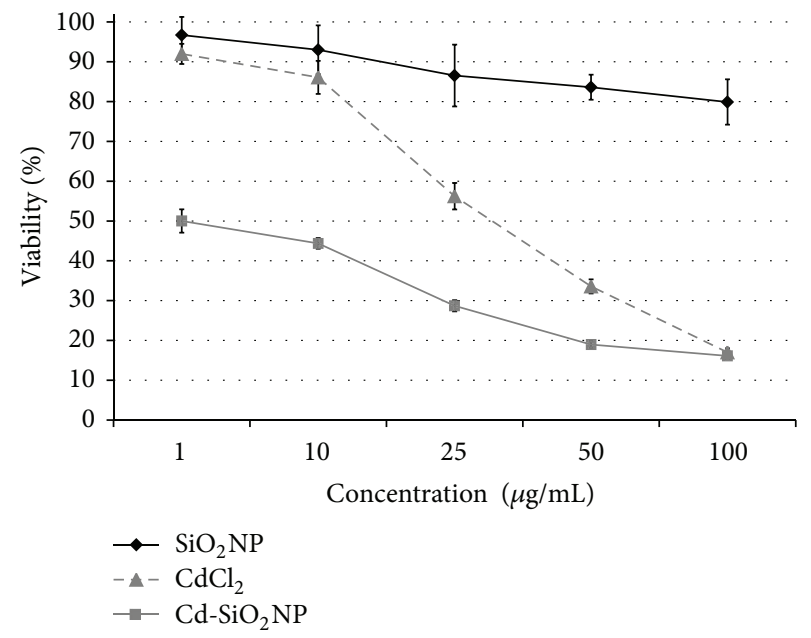

(b)

Figure 1: Cell viability measured by MTT assay in A549 cells exposed to increasing concentration (1-100 $\mu \mathrm{g} / \mathrm{mL})$ of Cd-SiO $\mathrm{NPs}_{2}(-\square-), \mathrm{CdCl}{ }_{2}$ $(-\triangle-)$, and $\mathrm{SiO}_{2} \mathrm{NPs}(-)$ after 24 (a) and $48 \mathrm{~h}(\mathrm{~b})$. Data are mean \pm DS of three separate experiments each carried out in six replicates. Error bars: \pm SD.

$\mathrm{CdCl}_{2}$, or $\mathrm{SiO}_{2} \mathrm{NPs}(1-100 \mu \mathrm{g} / \mathrm{mL})$ and expressed as percentage of the viability of control, are presented in Figures 1(a) and $1(\mathrm{~b})$. Both $\mathrm{Cd}-\mathrm{SiO}_{2} \mathrm{NPs}$ and $\mathrm{CdCl}_{2}$ produced a dosedependent cytotoxic effect on A549 cells. The pattern of cytotoxicity was similar at both time points (i.e., 24 and $48 \mathrm{~h}$ ) for either compound, but $\mathrm{Cd}-\mathrm{SiO}_{2} \mathrm{NP}$ cytotoxicity was more pronounced compared to $\mathrm{CdCl}_{2}$. $\mathrm{Cd}-\mathrm{SiO}_{2} \mathrm{NPs}$ induced mortality (about $40 \%$ and $50 \%$ after 24 and $48 \mathrm{~h}$ exposure resp.) already at the lowest dose $(1 \mu \mathrm{g} / \mathrm{mL}$ ) (Figures 1 (a) and 1(b)). The cytotoxic effect of $\mathrm{CdCl}_{2}$ treatment was detected at $25 \mu \mathrm{g} / \mathrm{mL}$ with about $20 \%$ mortality after $24 \mathrm{~h}$ (Figure 1(a)) and $45 \%$ after $48 \mathrm{~h}$ exposure (Figure $1(\mathrm{~b})$ ). The maximum effect (about $80 \%$ mortality) of the two tested materials reached at the highest dose $(100 \mu \mathrm{g} / \mathrm{mL})$ after $48 \mathrm{~h}$ exposure (Figure 1(b)).

As graphically represented, in Figures 1(a) and 1(b) (see black line), $\mathrm{SiO}_{2} \mathrm{NPs}$ did not show any significant cytotoxic effect after both time points considered ( 24 and $48 \mathrm{~h}$ ).

3.2.2. Membrane Integrity: Calcein-AM/PI Staining. Membrane integrity was evaluated by calcein-AM/PI staining after 24 and $48 \mathrm{~h}$ exposure to the compounds. Figures 2(a), 2(b), and 2(c) describe a panel of representative and randomly selected microscopic fields of A549 cells treated with increasing concentrations of $\mathrm{Cd}-\mathrm{SiO}_{2} \mathrm{NPs}, \mathrm{CdCl}_{2}$, and $\mathrm{SiO}_{2} \mathrm{NPs}(1-$ $100 \mu \mathrm{g} / \mathrm{mL}$ ) after $24 \mathrm{~h}$.

Calcein-AM/PI staining indicated cytotoxic effects. A similar dose-dependent cytotoxic effect was observed after both $\mathrm{Cd}-\mathrm{SiO}_{2} \mathrm{NPs}$ and $\mathrm{CdCl}_{2}$ treatments (Figures 2(a) and 2(b)). A decrease in cell viability was observed as evidenced by the presence of numerous red coloured cells (indicating damage to the cell membrane), starting at $25 \mu \mathrm{g} / \mathrm{mL}$ dose and becoming markedly evident at the highest concentrations of 50 and $100 \mu \mathrm{g} / \mathrm{mL}$ (Figures 2(a) and 2(b)). Semi-quantitative analysis of selected microscopic fields, after $24 \mathrm{~h}$ exposure, in terms of cell counts and expressed as percentage of live cells (green fluorescence), showed difference in cell death between $\mathrm{Cd}-\mathrm{SiO}_{2} \mathrm{NPs}$ and $\mathrm{CdCl}_{2}$ treatments at dose of $25 \mu \mathrm{g} / \mathrm{mL}$. Cd$\mathrm{SiO}_{2} \mathrm{NPs}$ mortality was higher than that caused by $\mathrm{CdCl}_{2}$ treatment (about $25 \%$ versus $4 \%$ ). In both $\mathrm{Cd}-\mathrm{SiO}_{2} \mathrm{NP}$ and $\mathrm{CdCl}_{2}$ groups treated with the lowest dose $(1 \mu \mathrm{g} / \mathrm{mL})$ the green fluorescence was uniformly diffused in cell cytoplasm (indicating the maintained membrane integrity), and cell morphology was not altered (Figures 2(a) and 2(b)).

The effects of $\mathrm{Cd}-\mathrm{SiO}_{2} \mathrm{NPs}$ and $\mathrm{CdCl}_{2}$ were exacerbated after $48 \mathrm{~h}$ exposure. Cell viability was decreased of about $60-$ $100 \%$ at doses ranging $25-100 \mu \mathrm{g} / \mathrm{mL}$ (data not shown).

Images obtained from $\mathrm{SiO}_{2} \mathrm{NP}$ treatment showed uniformly diffused green fluorescence and normal cell morphology for all treatment concentrations $(1-100 \mu \mathrm{g} / \mathrm{mL})$ when compared to control (Figure 2(c)). Semi-quantitative analysis with increasing concentrations of $\mathrm{SiO}_{2} \mathrm{NP}$ treatment (1$100 \mu \mathrm{g} / \mathrm{mL}$ ) showed no effects on A549 cells even at the highest dose investigated of $100 \mu \mathrm{g} / \mathrm{mL}$ and after both 24 (Figure 2(c)) and $48 \mathrm{~h}$ (data not shown).

3.2.3. Oxidative Stress: Evaluation of GSH Intracellular. GSH levels were affected by all test materials at both time points considered $(24-48 \mathrm{~h})$. The reduction of intracellular GSH levels caused by $\mathrm{Cd}-\mathrm{SiO}_{2} \mathrm{NP}$ or $\mathrm{CdCl}_{2}$ treatments was not dose-dependent: the $\mathrm{GSH}$ depletion was ranging from 35 to $40 \%$ and from 35 to $45 \%$ for $\mathrm{Cd}-\mathrm{SiO}_{2} \mathrm{NPs}$ and $\mathrm{CdCl}_{2}$, respectively, after $48 \mathrm{~h}$ exposure (Figure 3). $\mathrm{SiO}_{2} \mathrm{NPs}$ showed dose-depended depletion of GSH in cells when compared to control with about 55\% decrease of GSH intracellular after $48 \mathrm{~h}$ exposure at the highest concentration investigated $(100 \mu \mathrm{g} / \mathrm{mL}$; Figure 3).

3.2.4. Apoptotic Pathway: Immunofluorescence Analysis of Activated Caspase 3. Figure 4 displays a panel of representative randomly selected microscopic fields of A549 


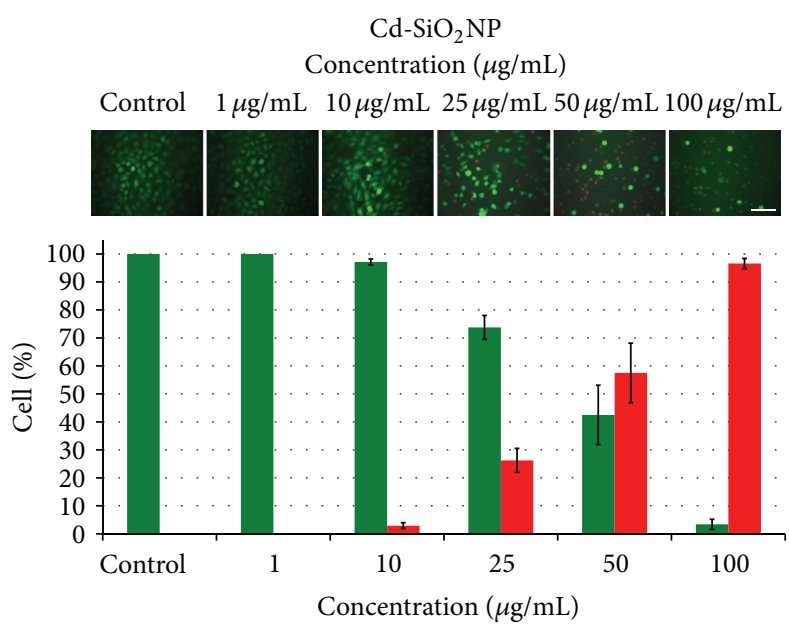

(a)

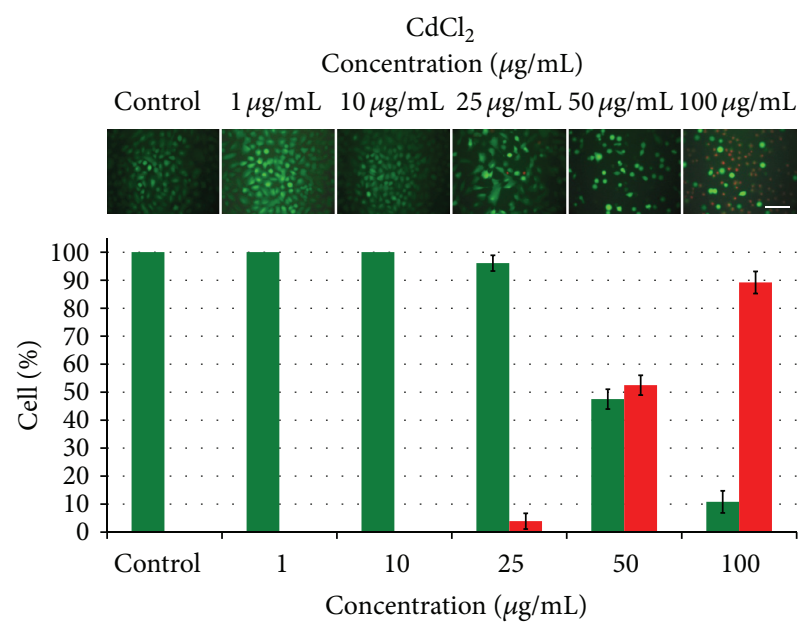

(b)

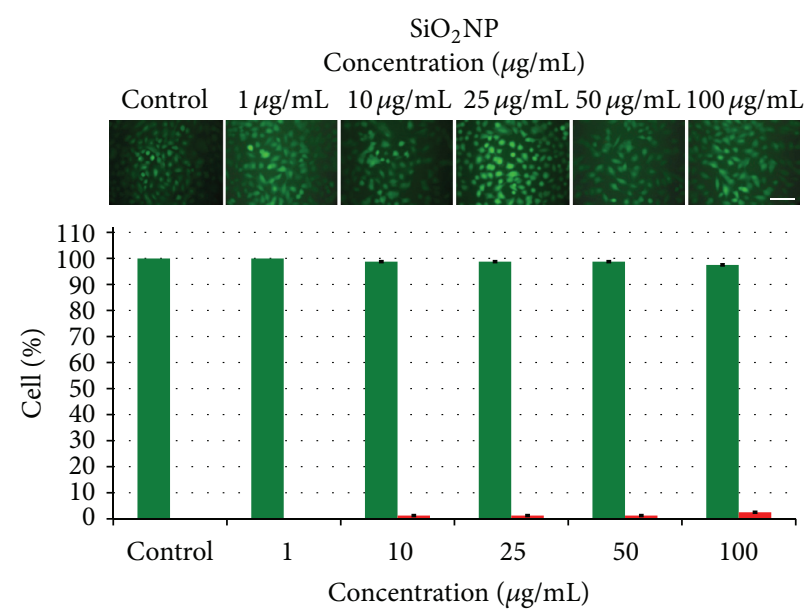

(c)

FIGURE 2: Representative images of randomly selected microscopic fields of A549 cells stained with calcein-AM/PI after $24 \mathrm{~h}$ exposure to increasing concentration (1-100 $\mathrm{\mu g} / \mathrm{mL}$ ) of Cd-SiO${ }_{2} \mathrm{NPs}(\mathrm{a}), \mathrm{CdCl}_{2}$ (b), and $\mathrm{SiO}_{2} \mathrm{NPs}(\mathrm{c})$. Dose-dependent cytotoxic effect in both Cd-SiO $\mathrm{NP}_{2}$ and $\mathrm{CdCl}_{2}$ treatment groups: there was a strong decrease of viability at higher concentrations ranging from 50 to $100 \mu \mathrm{g} / \mathrm{mL}$ (low or no green fluorescence and red fluorescence indicating cell death). $\mathrm{SiO}_{2} \mathrm{NPs}$ treated cells showed uniformly diffused green fluorescence at all tested doses similarly to cell controls. Quantitative analysis of the cell loss is shown for each treatment (Green Square Cell Live; Red Square Cell Death). Data are mean \pm DS of three separate experiments, error bars: \pm SD. (Scale bar: $100 \mu \mathrm{m})$.

cells treated with increasing concentrations of $\mathrm{Cd}-\mathrm{SiO}_{2} \mathrm{NPs}$, $\mathrm{CdCl}_{2}$, and $\mathrm{SiO}_{2} \mathrm{NPs}(1-50 \mu \mathrm{g} / \mathrm{mL})$. A549 cells exposed to $\mathrm{Cd}-\mathrm{SiO}_{2} \mathrm{NPs}$ or $\mathrm{CdCl}_{2}$ showed a progressive activation of caspase 3 as brilliant green intracellular spots (Figures 4(a)$4(\mathrm{~d})$ and Figures $4(\mathrm{e})-4(\mathrm{~h})$, resp.) directly observed with the lowest dose tested of $1 \mu \mathrm{g} / \mathrm{mL}$. To note, the advanced stage of apoptosis were observed at the highest dose of $50 \mu \mathrm{g} / \mathrm{mL}$ $\mathrm{Cd}$ for both $\mathrm{Cd}-\mathrm{SiO}_{2} \mathrm{NP}$ or $\mathrm{CdCl}_{2}$ treatments (Figures $4(\mathrm{a})-$ 4(d) and Figures 4(e)-4(h), resp.). In addition, a decrease in cell number along with a marked alteration of the morphology can be easily appreciated. On the contrary, the immunocytochemistry analysis to detect activated caspase 3 after $24 \mathrm{~h}$ exposure demonstrated no positivity for cells treated with $\mathrm{SiO}_{2} \mathrm{NPs}$ after any tested doses $(1-50 \mu \mathrm{g} / \mathrm{mL}$;
Figures 4(i)-4(l)) and no appreciable morphology alterations compared to control.

\subsection{Cytotoxicity Results after Long-Term Exposure (10 Days)}

3.3.1. Clonogenic Assay. To determine whether the prolonged exposure (up to 10 days) to increasing concentrations (0.05$100 \mu \mathrm{g} / \mathrm{mL}$ ) of $\mathrm{Cd}-\mathrm{SiO}_{2} \mathrm{NPs}, \mathrm{CdCl}_{2}$, and $\mathrm{SiO}_{2} \mathrm{NPs}$ might have adverse effects, the proliferation ability and colony forming capacity of A549 cells were evaluated. Figure 5 shows representative images of randomly selected microscopic fields of the different treatment groups $\left(\mathrm{Cd}-\mathrm{SiO}_{2} \mathrm{NPs}, \mathrm{CdCl}_{2}\right.$, and $\mathrm{SiO}_{2} \mathrm{NPs}$ ). The colonies of $\mathrm{SiO}_{2} \mathrm{NP}$ groups (Figures 5(a)$5(\mathrm{e}))$ had roundish colony morphology and similar patterns 


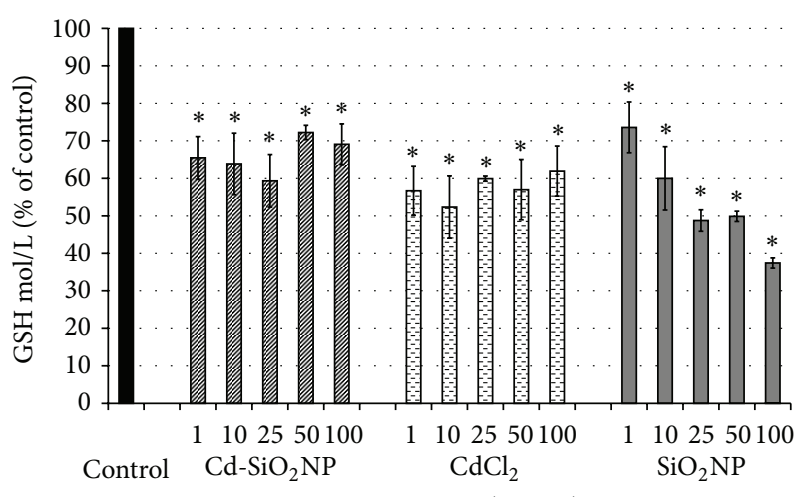

Concentration $(\mu \mathrm{g} / \mathrm{mL})$

FIGURE 3: Glutathione (GSH) measurement in A549 cells unexposed (control) and exposed to increasing concentrations $(1-100 \mu \mathrm{g} / \mathrm{mL}$ ) of $\mathrm{Cd}-\mathrm{SiO}_{2} \mathrm{NPs}, \mathrm{CdCl}_{2}, \mathrm{SiO}_{2} \mathrm{NPs}$ after $48 \mathrm{~h}$. GSH levels were affected by all tested materials: the GSH depletion in A549 cells was not dosedependent after $\mathrm{Cd}-\mathrm{SiO}_{2} \mathrm{NP}$ or $\mathrm{CdCl}_{2}$ treatments, while was dosedepended after $\mathrm{SiO}_{2} \mathrm{NP}$ treatments. Data are mean \pm DS of three separate experiments each carried out in six replicates. ${ }^{*} P<0.05$ significant difference from control.

to control (data not shown), while, A549 cells treated with doses ranging from 0.05 to $10 \mu \mathrm{g} / \mathrm{mL}$ of $\mathrm{Cd}-\mathrm{SiO}_{2} \mathrm{NPs}$ and $\mathrm{CdCl}_{2}$ presented few colonies and a drastic reduced size compared to control (data not shown, Figures $5(\mathrm{f})-5(\mathrm{j})$, and Figures $5(\mathrm{k})-5(\mathrm{o})$, resp.). At the higher concentrations of either $\mathrm{Cd}-\mathrm{SiO}_{2} \mathrm{NPs}$ or $\mathrm{CdCl}_{2}$ (25 to $100 \mu \mathrm{g} / \mathrm{mL}$ ) there was a complete inhibition of the colony formation.

Semi-quantitative analysis showed a strong reduction of colony number (about $45 \%$ ) already at the lowest tested dose $(0.05 \mu \mathrm{g} / \mathrm{mL})$ for both $\mathrm{Cd}-\mathrm{SiO}_{2} \mathrm{NPs}$ and $\mathrm{CdCl}_{2}$ treatments, until reaching a total inhibition of cell proliferation at the doses from 25 to $100 \mu \mathrm{g} / \mathrm{mL}$ (Figure 6). $\mathrm{SiO}_{2} \mathrm{NP}$ treatment did not produce adverse effects, indeed the proliferative activity of A549 cells was not inhibited after prolonged exposure to any $\mathrm{SiO}_{2} \mathrm{NP}$ dose tested $(0.05-100 \mu \mathrm{g} / \mathrm{mL}$; Figure 6).

\section{Discussion}

The present in vitro investigations indicate that $\mathrm{Cd}-\mathrm{SiO}_{2} \mathrm{NP}$ treatment produced in vitro deleterious effects after short(24-48 h) and long-term (up to 10 days) exposure with mitochondrial function severely impaired and activation of caspase-3, depletion of GSH, and inhibition of cell proliferation already observable at the lowest concentration doses (i.e., $1 \mu \mathrm{g} / \mathrm{mL}$ for the short-term exposure and $0.05 \mu \mathrm{g} / \mathrm{mL}$ for the prolonged exposure). Similar cytotoxic profile was observed after $\mathrm{CdCl}_{2}$ treatment. However, the magnitude of effects caused by $\mathrm{Cd}-\mathrm{SiO}_{2} \mathrm{NPs}$ was more pronounced compared to that produced by $\mathrm{CdCl}_{2}$.

A549 acutely exposed to $\mathrm{Cd}-\mathrm{SiO}_{2} \mathrm{NPs}$ showed dosedependent alterations of mitochondrial function and membrane integrity, as well as activation of caspase- 3 already after $24 \mathrm{~h}$ exposure. At 48 -hr, a further exacerbation of these effects was assessed. $\mathrm{CdCl}_{2}$ also influenced the same cellular parameters although the effects were less pronounced than those caused by $\mathrm{Cd}-\mathrm{SiO}_{2} \mathrm{NPs}$. On the contrary, $\mathrm{SiO}_{2} \mathrm{NPs}$ did not induce cytotoxic effects in this cell model.

Intracellular GSH level changes (decreases) were also observed at both time-points ( 24 and $48 \mathrm{~h}$ ) in A549 cells for all tested compounds $\left(\mathrm{Cd}-\mathrm{SiO}_{2} \mathrm{NPs}, \mathrm{CdCl}_{2}\right.$, and $\left.\mathrm{SiO}_{2} \mathrm{NPs}\right)$ suggesting an induction of oxidative stress. Notably, GSH level was the only altered parameter following $\mathrm{SiO}_{2} \mathrm{NP}$ exposure.

Clonogenic assay, used to evaluate the effects induced after prolonged exposure (10 days), showed the ability of both $\mathrm{Cd}-\mathrm{SiO}_{2} \mathrm{NPs}$ and $\mathrm{CdCl}_{2}$ (at the lowest tested dose of $0.05 \mu \mathrm{g} / \mathrm{mL}$ ) to drastically inhibit A549 cell proliferation, while, once again, $\mathrm{SiO}_{2} \mathrm{NPs}$ were avoided of any effect.

In relation to cadmium toxicity, an extensive database is available on $\mathrm{CdCl}_{2}$-induced pneumotoxicant effects by in vivo and in vitro models [22]. Mechanistically, $\mathrm{Cd}$, at the cellular level, has been shown to cause oxidative stress by depletion of endogenous antioxidants such as glutathione that is associated with mitochondrial damage and induction of apoptosis $[8,34]$. A recent in vitro study underlined that low-dose cadmium triggers apoptosis rather than outright necrosis [35]. Indeed $\mathrm{CdCl}_{2}$ concentrations used in proximal tubule (PT) cell culture model to induce apoptosis ranged from 2 to $10 \mu \mathrm{g} / \mathrm{mL}$ (corresponding to $10-50 \mu \mathrm{M}$ ) [37]. For instance, these values are of similar magnitude as the threshold level of $50 \mu \mathrm{g} / \mathrm{g}$ kidney tissue for the development of signs of kidney dysfunction and PT damage indicated in in vivo experimental and human studies of chronic $\mathrm{Cd}^{2+}[38$, 39]. Involvement of caspase- 3 has been described in several animal models of chronic $\mathrm{Cd}^{2+}$ nephrotoxicity $[40,41]$.

Apoptosis (5-fold higher than control) was also observed in cultures, of rat lung epithelial cell line, exposed for $48 \mathrm{~h}$ to $20 \mu \mathrm{M} \mathrm{CdCl}_{2}$ [42], and was preceded by the up-regulation of oxidant stress genes (glutathione S-transferase-alpha, gamma-glutamylcysteine synthetase, and metallothionein1), activation of redox sensitive transcription factors (AP-1 and NF- $\kappa \mathrm{B}$ ), and changes in various forms of glutathione (reduced, oxidized, and protein-bound); thus, altogether, these features suggesting a key role played by the reactive oxygen species.

Our findings indeed evidenced, after both $\mathrm{Cd}-\mathrm{SiO}_{2} \mathrm{NPs}$ and $\mathrm{CdCl}_{2}$, GSH depletion and activation of caspase-3 which is a critical executioner of apoptosis, as it is either partially or totally responsible for the proteolytic cleavage of many key proteins [43].

The observed cytotoxic effects induced by $\mathrm{Cd}-\mathrm{SiO}_{2} \mathrm{NPs}$ after short-and long-term exposure suggest a crucial role of the cadmium moiety in the biological response to $\mathrm{Cd}$ $\mathrm{SiO}_{2}$ NPs although it seems unlikely that the changes produced by $\mathrm{Cd}-\mathrm{SiO}_{2} \mathrm{NPs}$ merely reflected the action of cadmium ions released from nanoparticles. Indeed, chemical experiments with $\mathrm{Cd}-\mathrm{SiO}_{2} \mathrm{NPs}$ have demonstrated limited release of cadmium ions from the nanoparticles dispersed in medium culture, the maximum metal release being ca. $28 \%$ over a 10-day period.

In addition, the tendency to form aggregates and agglomerates of these doped NPs [29] may also have contributed 


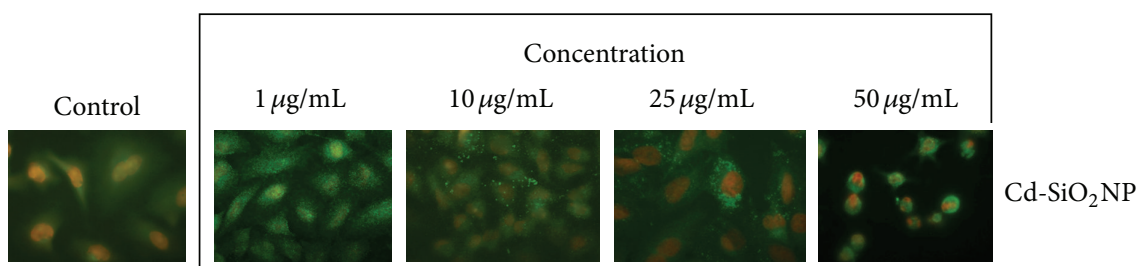

(a)
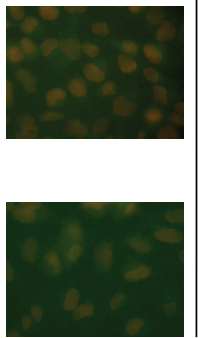

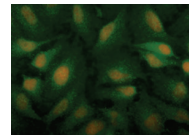

(e)

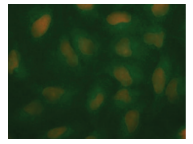

(i) (b)

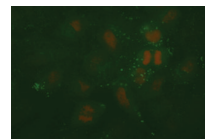

(f)

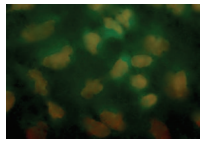

(j) (c)

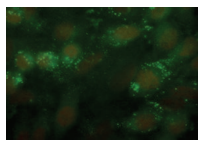

(g)

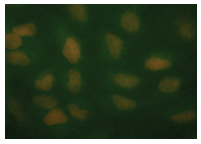

(k) (d)

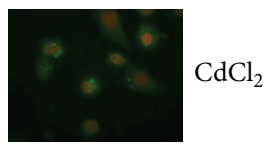

(h)

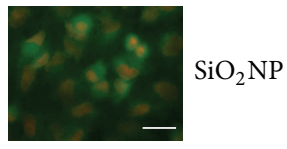

(1)

FIGURE 4: Representative images of randomly selected microscopic fields of A549 cells marked with caspase 3 antibody after $24 \mathrm{~h}$ incubation with: $\mathrm{Cd}-\mathrm{SiO}_{2} \mathrm{NPs}((\mathrm{a})-(\mathrm{d})), \mathrm{CdCl}_{2}((\mathrm{e})-(\mathrm{h})), \mathrm{SiO}_{2} \mathrm{NPs}((\mathrm{i})-(\mathrm{l}))$ at the doses indicated in the figure. Activation of caspase 3 is indicated by green spots already at the lowest tested dose of $1 \mu \mathrm{g} / \mathrm{mL}$ in both $\mathrm{Cd}-\mathrm{SiO}_{2} \mathrm{NP}$ and $\mathrm{CdCl}_{2}$ treatment groups, while there was no positivity in $\mathrm{SiO}_{2} \mathrm{NPs}$ treated cells at all the tested doses similarly to the unexposed cells (control). (Scale bar: $100 \mu \mathrm{m}$ ).

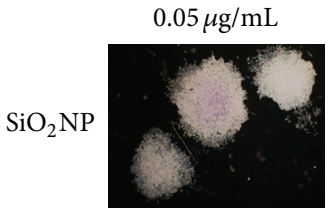

(a)

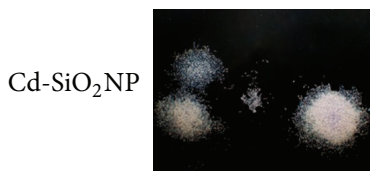

(f)

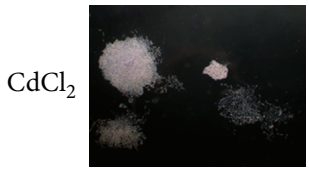

(k)
$0.1 \mu \mathrm{g} / \mathrm{mL}$

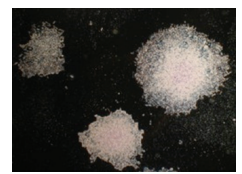

(b)

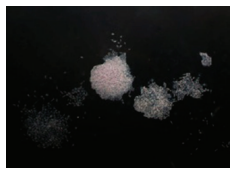

(g)

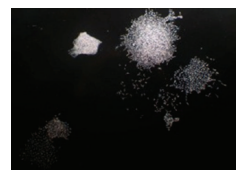

(1)
Concentration

$0.2 \mu \mathrm{g} / \mathrm{mL}$

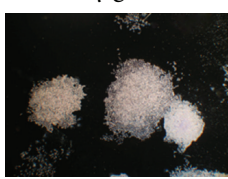

(c)

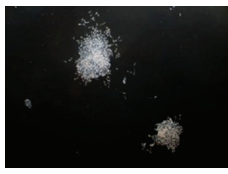

(h)

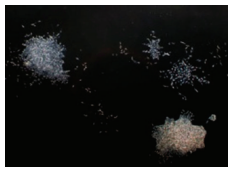

(m)
$1 \mu \mathrm{g} / \mathrm{mL}$

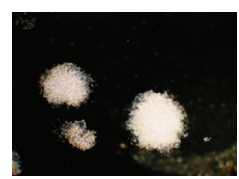

(d)

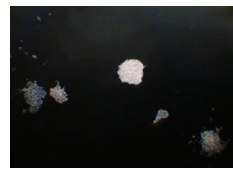

(i)

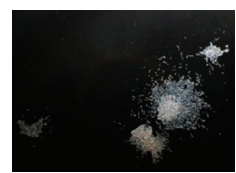

(n)
$10 \mu \mathrm{g} / \mathrm{mL}$

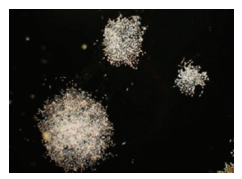

(e)

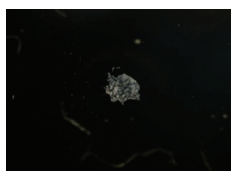

(j)

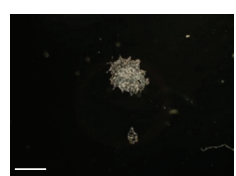

(o)

FIGURE 5: Representative images of randomly selected microscopic fields of the colonies formed after 10 consecutive days exposure to increasing concentrations $(0.05-100 \mu \mathrm{g} / \mathrm{mL})$ of $\mathrm{Cd}-\mathrm{SiO}_{2} \mathrm{NPs}, \mathrm{CdCl}_{2}$, and $\mathrm{SiO}_{2} \mathrm{NPs} \mathrm{SiO}_{2} \mathrm{NP}$ colonies showed similar patterns at the all tested doses to the control (control data not shown). Few colonies with reduced size compared to control were observed at the lower concentrations $(0.05-10 \mu \mathrm{g} / \mathrm{mL})$ of $\mathrm{Cd}-\mathrm{SiO}_{2} \mathrm{NPs}$ and $\mathrm{CdCl}_{2}$, while there was a total inhibition of the colonies at the higher tested doses $(25-100 \mu \mathrm{g} / \mathrm{mL})$ for both $\mathrm{Cd}-\mathrm{SiO}_{2} \mathrm{NPs}_{\text {and }} \mathrm{CdCl}_{2}$. (Scale bar: $600 \mu \mathrm{m}$ ).

in triggering the described $\mathrm{Cd}-\mathrm{SiO}_{2} \mathrm{NP}$ effects: the DLS data demonstrated an agglomeration and aggregation extent of $\mathrm{Cd}-\mathrm{SiO}_{2} \mathrm{NPs}$ (about $350 \mathrm{~nm}$ ) greater than that measured for $\mathrm{SiO}_{2} \mathrm{NPs}$ (about $120 \mathrm{~nm}$ ). Whether those agglomerated particles retain toxic properties of the individual nanoparticles or are capable of subsequently is a critical question [44].

An additional hypothesis may be related to the nano dimension of the material investigated. In our in vitro experiments, the nano dimension may have facilitated the cell concentration and thus toxicity of the administered cadmium. A "Trojan horse"-type mechanism involving silica nanoparticles as effective carriers for the cellular uptake of toxic metals has been described [45]. In the same type of lung cells used in this study, exposure to $\mathrm{SiO}_{2} \mathrm{NPs}$ doped with metals such as iron, manganese, cobalt, or titanium was shown to generate higher concentrations of reactive oxygen species and induce more severe oxidative stress compared to equivalent amounts of the respective metal ions [46]. In our 


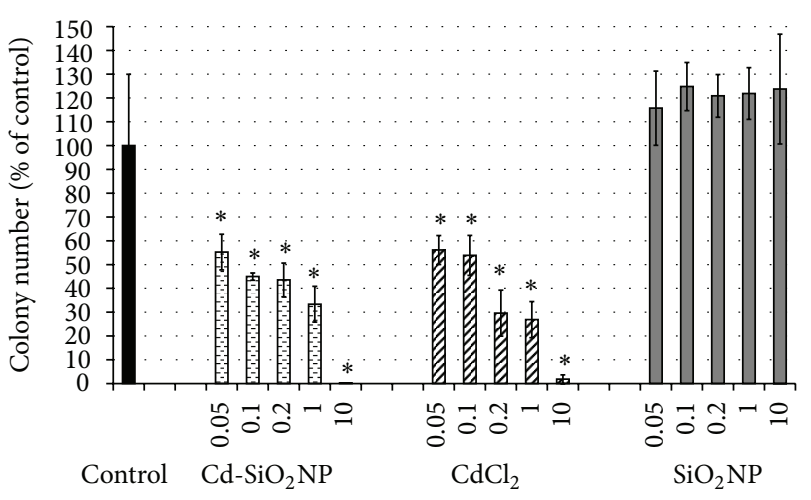

Concentration $(\mu \mathrm{g} / \mathrm{mL})$

FIGURE 6: Histograms show the number of colonies formed after 10 consecutive days exposure to increasing concentrations of Cd$\mathrm{SiO}_{2} \mathrm{NPs}, \mathrm{CdCl}_{2}, \mathrm{SiO}_{2} \mathrm{NPs}$ at the doses indicated in the figure. The formation of A549 colonies appeared to be serious compromised by both $\mathrm{Cd}-\mathrm{SiO}_{2} \mathrm{NP}$ and $\mathrm{CdCl}_{2}$ treatments already at the lowest dose of $0.05 \mu \mathrm{g} / \mathrm{mL}$, while $\mathrm{SiO}_{2} \mathrm{NPs}_{2}$ had no effects on their formation. Data are mean \pm DS of two separate experiments each carried out in three replicates, expressed as percentage of control colonies. ${ }^{*} P<0.05$ significant difference from control. Error bars: \pm SD.

study, incorporation of $\mathrm{Cd}$ into $\mathrm{SiO}_{2} \mathrm{NPs}$ may have increased the metal dose delivered to target cells although no specific data supporting this process are presently available.

With regard to $\mathrm{SiO}_{2} \mathrm{NPs}$, no cytotoxic effects were observed for all concentrations tested and for all exposure times (acute or chronic), with the only exception for the observed GSH depletion after $48 \mathrm{~h}$ treatment. Several recent literature data are consistent with the present findings: $\mathrm{SiO}_{2} \mathrm{NPs}$ penetrated A549 cells and did not cause significant toxic effects at the molecular and cellular levels below $100 \mu \mathrm{g} / \mathrm{mL}$ [47]; it induced low cytotoxicity at concentrations up to $200 \mu \mathrm{g} / \mathrm{mL}$ [48], and generated oxidative stress reflected by reduction of GSH levels [16] or oxidant generation [49]. On the other hand, other investigations indicated A549 cell viability decreases after $\mathrm{SiO}_{2}$ NPs exposure down to $100 \mu \mathrm{g} / \mathrm{mL}$ [16], as well as a proinflammatory response triggered by $\mathrm{SiO}_{2} \mathrm{NPs}$ without blocking cell proliferation or causing cell death in A549 cells [50].

For comparison, our previous in vivo results indicated early and persistent lung damage after i.t. instillation of $\mathrm{Cd}-\mathrm{SiO}_{2} \mathrm{NPs}$ in terms of enhanced apoptotic phenomena followed by a significant increase of proliferating cells [29], as well as pulmonary inflammation and fibrosis in rats evidenced by a wide-spread immunoreactivity of both cytokines/chemokines and collagen, respectively. The effects were detectable at the earliest time point, $24 \mathrm{~h}$, and persisted until the 30th day post exposure. Similar pattern of toxic insult was also revealed after i.t. instillation of equivalent amount of $\mathrm{CdCl}_{2}$, although it was less marked than Cd-SiO${ }_{2} \mathrm{NP}$ treatment. The dose of $\mathrm{CdCl}_{2}$ per animal was $400 \mu \mathrm{g}(2.1 \mu \mathrm{mol}) \equiv$ $247 \mu \mathrm{g} \mathrm{Cd}$. Cd-SiO${ }_{2} \mathrm{NPs}$ and $\mathrm{CdCl}_{2}$ also showed the capacity to cause long-lasting oxidative stress by increasing the tissue $\mathrm{F}_{2}$-isoprostane levels and pulmonary SOD1, COX-2, and iNOS expressions [30].
On the contrary, no changes involving these markers were observed in animals treated with $\mathrm{SiO}_{2} \mathrm{NPs}$.

Altogether, the in vivo results showed a higher Cd$\mathrm{SiO}_{2} \mathrm{NPs}$ reactivity (regardless of whether form type is present: original, agglomerate, or with sorbed material at NP surface) than $\mathrm{SiO}_{2} \mathrm{NPs}$ and $\mathrm{CdCl}_{2}$ in the lung tissue.

Both in vitro and in vivo findings pointed out that $\mathrm{Cd}$ $\mathrm{SiO}_{2} \mathrm{NP}$ exposure produces a complex and multicomponent insult leading to an exacerbated toxicity response compared to the toxic pattern caused by $\mathrm{CdCl}_{2}$ treatment and essentially much more than $\mathrm{SiO}_{2} \mathrm{NPs}$.

\section{Conclusions}

In vitro experiments in pulmonary cells have provided effective means of screening and ranking the tested materials $(\mathrm{Cd}-$ $\mathrm{SiO}_{2} \mathrm{NPs}>\mathrm{CdCl}_{2}>\mathrm{SiO}_{2} \mathrm{NPs}$ ) using multiple toxicological endpoints (i.e., mitochondrial and membrane alterations, induction of apoptosis, inhibition of growth and proliferation, and intracellular GSH depletion). Coherently, the in vivo results have systematically characterized the tissue damage evidenced by lung parenchyma injury and fibrosis, apoptotic phenomena, the occurrence of inflammation, and pulmonary oxidative stress in rats. The in vivo targeted tests have complemented and addressed the in vitro findings to ensure the adequate evaluation of nanoparticle hazard potential, also in terms of time of appearance and persistence of the toxicological features on living organism.

\section{Highlights}

(i) $\mathrm{Cd}-\mathrm{SiO}_{2} \mathrm{NPs}$ produced in vitro toxic effects after short- and long-term exposure;

(ii) similar toxic profile was observed after $\mathrm{CdCl}_{2}$, the effect rank: $\mathrm{Cd}-\mathrm{SiO}_{2} \mathrm{NPs}>\mathrm{CdCl}_{2}$;

(iii) $\mathrm{SiO}_{2} \mathrm{NPs}$ influenced oxidative stress pathway only;

(iv) In vitro tests on lung cells provided effective means of ranking the tested materials.

\section{Conflict of Interests}

The authors declare that they have no conflict of interests and they alone are responsible for content and writing of the paper.

\section{Acknowledgments}

The paper was supported by Grants from the Italian Ministries of Health, Research, and Education, and the CARIPLO Foundation (Rif. 2011-2096). The authors wish to acknowledge Dr Croce Anna Cleta, Histochemistry and Cytometry Unit IGM-CNR, Pavia, for the scientific contributions to immunofluorescence analysis.

\section{References}

[1] F. Marano, S. Hussain, F. Rodrigues-Lima, A. Baeza-Squiban, and S. Boland, "Nanoparticles: molecular targets and cell signalling," Archives of Toxicology, vol. 85, no. 7, pp. 733-741, 2011. 
[2] A. D. Maynard, R. J. Aitken, T. Butz et al., "Safe handling of nanotechnology," Nature, vol. 444, no. 7117, pp. 267-269, 2006.

[3] G. Oberdörster, E. Oberdörster, and J. Oberdörster, "Nanotoxicology: an emerging discipline evolving from studies of ultrafine particles," Environmental Health Perspectives, vol. 113, no. 7, pp. 823-839, 2005.

[4] G. Oberdörster, A. Maynard, K. Donaldson et al., "Principles for characterizing the potential human health effects from exposure to nanomaterials: elements of a screening strategy," Particle and Fibre Toxicology, vol. 2, article 8, 2005.

[5] N. Ahmed, H. Fessi, and A. Elaissari, "Theranostic applications of nanoparticles in cancer," Drug Discovery Today, vol. 17, no. 19-20, pp. 1147-1154, 2012.

[6] M. Mahmoudi, V. Serpooshan, and S. Laurent, "Engineered nanoparticles for biomolecular imaging," Nanoscale, vol. 3, no. 8, pp. 3007-3026, 2011.

[7] V. Mamaeva, C. Sahlgren, and M. Lindén, "Mesoporous silica nanoparticles in medicine-recent advances," Advanced Drug Delivery Reviews, vol. 65, no. 5, pp. 689-702, 2013.

[8] B. A. Rzigalinski and J. S. Strobl, "Cadmium-containing nanoparticles: perspectives on pharmacology and toxicology of quantum dots," Toxicology and Applied Pharmacology, vol. 238, no. 3, pp. 280-288, 2009.

[9] S. Simovic, N. Ghouchi-Eskandar, A. M. Sinn, D. Losic, and C. A. Prestidge, "Silica materials in drug delivery applications," Current Drug Discovery Technologies, vol. 8, no. 3, pp. 269-276, 2011.

[10] J. L. Vivero-Escoto, I. I. Slowing, B. G. Trewyn, and V. S.-Y. Lin, "Mesoporous silica nanoparticles for intracellular controlled drug delivery," Small, vol. 6, no. 18, pp. 1952-1967, 2010.

[11] W.-S. Cho, M. Choi, B. S. Han et al., "Inflammatory mediators induced by intratracheal instillation of ultrafine amorphous silica particles," Toxicology Letters, vol. 175, no. 1-3, pp. 24-33, 2007.

[12] H.-J. Eom and J. Choi, "Oxidative stress of silica nanoparticles in human bronchial epithelial cell, Beas-2B," Toxicology in Vitro, vol. 23, no. 7, pp. 1326-1332, 2009.

[13] E. Gazzano, M. Chiazza, M. Polimeri et al., "Physicochemical determinants in the cellular responses to nanostructured amorphous silicas," Toxicological Sciences, vol. 128, no. 1, pp. 158-170, 2012.

[14] T. Kaewamatawong, A. Shimada, M. Okajima et al., "Acute and subacute pulmonary toxicity of low dose of ultrafine colloidal silica particles in mice after intratracheal instillation," Toxicologic Pathology, vol. 34, no. 7, pp. 958-965, 2006.

[15] W.-K. Lee, B. Torchalski, N. Kohistani, and F. Thévenod, "ABCB1 protects kidney proximal tubule cells against cadmiuminduced apoptosis: roles of cadmium and ceramide transport," Toxicological Sciences, vol. 121, no. 2, pp. 343-356, 2011.

[16] W. Lin, Y.-W. Huang, X.-D. Zhou, and Y. Ma, "In vitro toxicity of silica nanoparticles in human lung cancer cells," Toxicology and Applied Pharmacology, vol. 217, no. 3, pp. 252-259, 2006.

[17] D. Napierska, L. C. J. Thomassen, D. Lison, J. A. Martens, and P. H. Hoet, "The nanosilica hazard: another variable entity," Particle and Fibre Toxicology, vol. 7, article 39, 2010.

[18] A. Panas, C. Marquardt, O. Nalcaci et al., "Screening of different metal oxide nanoparticles reveals selective toxicity and inflammatory potential of silica nanoparticles in lung epithelial cells and macrophages," Nanotoxicology, vol. 7, no. 3, pp. 259-273, 2013.
[19] E.-J. Park and K. Park, "Oxidative stress and pro-inflammatory responses induced by silica nanoparticles in vivo and in vitro," Toxicology Letters, vol. 184, no. 1, pp. 18-25, 2009.

[20] S. Nogué, P. Sanz-Gallén, A. Torras, and F. Boluda, "Chronic overexposure to cadmium fumes associated with IgA mesangial glomerulonephritis," Occupational Medicine, vol. 54, no. 4, pp. 265-267, 2004.

[21] G. F. Nordberg, K. Onawa, M. Nordberg, and L. T. Friberg, "Cadmium," in Handbook of Toxicology of Metals, G. F. Nordberg, B. A. Fowler, M. Nordberg, and L. Friberg, Eds., Elsevier, Amsterdam, The Netherlands, 2007.

[22] Agency for Toxic Substances and Disease Registry (ATSDR), "Toxicological profile for Cadmium," Atlanta, Ga, USA, Department of Health and Human Services, Public Health Service, 2008.

[23] US EPA, "Draft nanomaterial research strategy," (NRS) EPA/ 600/S-08/002, United States Environmental Protection Agency, 2008.

[24] US National Cancer Institute-Nanotechnology Characterization Laboratory, http://ncl.cancer.gov/working_assay-cascade.asp.

[25] D. B. Warheit, P. J. A. Borm, C. Hennes, and J. Lademann, "Testing strategies to establish the safety of nanomaterials: conclusions of an ECETOC workshop," Inhalation Toxicology, vol. 19, no. 8, pp. 631-643, 2007.

[26] M. A. Maurer-Jones and C. L. Haynes, "Toward correlation in in vivo and in vitro nanotoxicology studies," The Journal of Law, Medicine \& Ethics, vol. 40, no. 4, pp. 795-801, 2013.

[27] S. Creton, I. C. Dewhurst, L. K. Earl et al., "Acute toxicity testing of chemicals-opportunities to avoid redundant testing and use alternative approaches," Critical Reviews in Toxicology, vol. 40, no. 1, pp. 50-83, 2010.

[28] REACH (Registration Evaluation AuthorizationandRestriction of Chemicals), Regulation (EC) No 1907/2006, 2006, http://eurlex.europa.eu/LexUriServ/LexUriServ.do?uri=oj:1:2006:396:0001: 0849:en:pdf.

[29] T. Coccini, S. Barni, R. Vaccarone, P. Mustarelli, L. Manzo, and E. Roda, "Pulmonary toxicity of instilled cadmium-doped silica nanoparticles during acute and subacute stages in rats," Histology and Histopathology, vol. 28, no. 2, pp. 195-209, 2013.

[30] T. Coccini, E. Roda, S. Barni, C. Signorini, and L. Manzo, "Longlasting oxidative pulmonary insult in rat after intratracheal instillation of silica nanoparticles doped with cadmium," Toxicology, vol. 302, pp. 203-211, 2012.

[31] C. Jumarie, "Cadmium transport through type II alveolar cell monolayers: contribution of transcellular and paracellular pathways in the rat ATII and the human A549 cells," Biochimica et Biophysica Acta, vol. 1564, no. 2, pp. 487-499, 2002.

[32] K. Y. Kwon, J. H. Jang, W. I. Choi, S. Ramachandran, C. H. Cho, and P. T. Cagle, "Expression of apoptotic nuclei by ultrastructural terminal deoxyribonucleotidyl transferase mediated dUTP nick end labeling and detection of FasL, caspases and PARP protein molecules in cadmium induced acute alveolar cell injury," Toxicology, vol. 218, no. 2-3, pp. 197-204, 2006.

[33] W.-K. Lee and F. Thévenod, "Novel roles for ceramides, calpains and caspases in kidney proximal tubule cell apoptosis: lessons from in vitro cadmium toxicity studies," Biochemical Pharmacology, vol. 76, no. 11, pp. 1323-1332, 2008.

[34] F. Thévenod, "Cadmium and cellular signaling cascades: to be or not to be?" Toxicology and Applied Pharmacology, vol. 238, no. 3, pp. 221-239, 2009. 
[35] H. Zhang, D. R. Newman, J. C. Bonner, and P. L. Sannes, “Overexpression of human endosulfatase-1 exacerbates cadmiuminduced injury to transformed human lung cells in vitro," Toxicology and Applied Pharmacology, vol. 265, no. 1, pp. 27-42, 2012.

[36] E. Herzog, A. Casey, F. M. Lyng, G. Chambers, H. J. Byrne, and M. Davoren, "A new approach to the toxicity testing of carbonbased nanomaterials-The clonogenic assay," Toxicology Letters, vol. 174, no. 1-3, pp. 49-60, 2007.

[37] W.-K. Lee, M. Abouhamed, and F. Thévenod, "Caspase-dependent and -independent pathways for cadmium-induced apoptosis in cultured kidney proximal tubule cells," American Journal of Physiology_Renal Physiology, vol. 291, no. 4, pp. F823-F832, 2006.

[38] L. Järup, M. Berglund, C. G. Elinder, G. Nordberg, and M. Vahter, "Health effects of cadmium exposure-a review of the literature and a risk estimate (Scandinavian Journal of Work, Environment and Health (1998) 24, suppl 1 (52))," Scandinavian Journal of Work, Environment and Health, vol. 24, no. 3, p. 240, 1998.

[39] S. Thijssen, J. Maringwa, C. Faes, I. Lambrichts, and E. Van Kerkhove, "Chronic exposure of mice to environmentally relevant, low doses of cadmium leads to early renal damage, not predicted by blood or urine cadmium levels," Toxicology, vol. 229, no. 1-2, pp. 145-156, 2007.

[40] T. Aoyagi, K. Hayakawa, K. Miyaji, H. Ishikawa, and M. Hata, "Cadmium nephrotoxicity and evacuation from the body in a rat modeled subchronic intoxication," International Journal of Urology, vol. 10, no. 6, pp. 332-338, 2003.

[41] Y. Liu, J. Liu, S. M. Habeebu, M. P. Waalkes, and C. D. Klaassen, "Metallothionein-I/II null mice are sensitive to chronic oral cadmium-induced nephrotoxicity," Toxicological Sciences, vol. 57, no. 1, pp. 167-176, 2000.

[42] B. A. Hart, C. H. Lee, G. S. Shukla et al., "Characterization of cadmium-induced apoptosis in rat lung epithelial cells: evidence for the participation of oxidant stress," Toxicology, vol. 133, no. 1, pp. 43-58, 1999.

[43] X.-M. Sun, M. MacFarlane, J. Zhuang, B. B. Wolf, D. R. Green, and G. M. Cohen, "Distinct caspase cascades are initiated in receptor-mediated and chemical-induced apoptosis," The Journal of Biological Chemistry, vol. 274, no. 8, pp. 5053-5060, 1999.

[44] J. M. Balbus, A. D. Maynard, V. L. Colvin et al., "Meeting report: hazard assessment for nanoparticles-report from an interdisciplinary workshop," Environmental Health Perspectives, vol. 115, no. 11, pp. 1654-1659, 2007.

[45] E.-J. Park, J. Yi, Y. Kim, K. Choi, and K. Park, "Silver nanoparticles induce cytotoxicity by a Trojan-horse type mechanism," Toxicology in Vitro, vol. 24, no. 3, pp. 872-878, 2010.

[46] L. K. Limbach, P. Wick, P. Manser, R. N. Grass, A. Bruinink, and W. J. Stark, "Exposure of engineered nanoparticles to human lung epithelial cells: influence of chemical composition and catalytic activity on oxidative stress," Environmental Science and Technology, vol. 41, no. 11, pp. 4158-4163, 2007.

[47] Y. Jin, S. Kannan, M. Wu, and J. X. Zhao, "Toxicity of luminescent silica nanoparticles to living cells," Chemical Research in Toxicology, vol. 20, no. 8, pp. 1126-1133, 2007.

[48] Y. Shi, S. Yadav, F. Wang, and H. Wang, "Endotoxin promotes adverse effects of amorphous silica nanoparticles on lung epithelial cells in vitro," Journal of Toxicology and Environmental Health A, vol. 73, no. 11, pp. 748-756, 2010.

[49] M. J. Akhtar, M. Ahamed, S. Kumar et al., "Nanotoxicity of pure silica mediated through oxidant generation rather than glutathione depletion in human lung epithelial cells," Toxicology, vol. 276, no. 2, pp. 95-102, 2010.

[50] S.-J. Choi, J.-M. Oh, and J.-H. Choy, "Toxicological effects of inorganic nanoparticles on human lung cancer A549 cells," Journal of Inorganic Biochemistry, vol. 103, no. 3, pp. 463-471, 2009. 

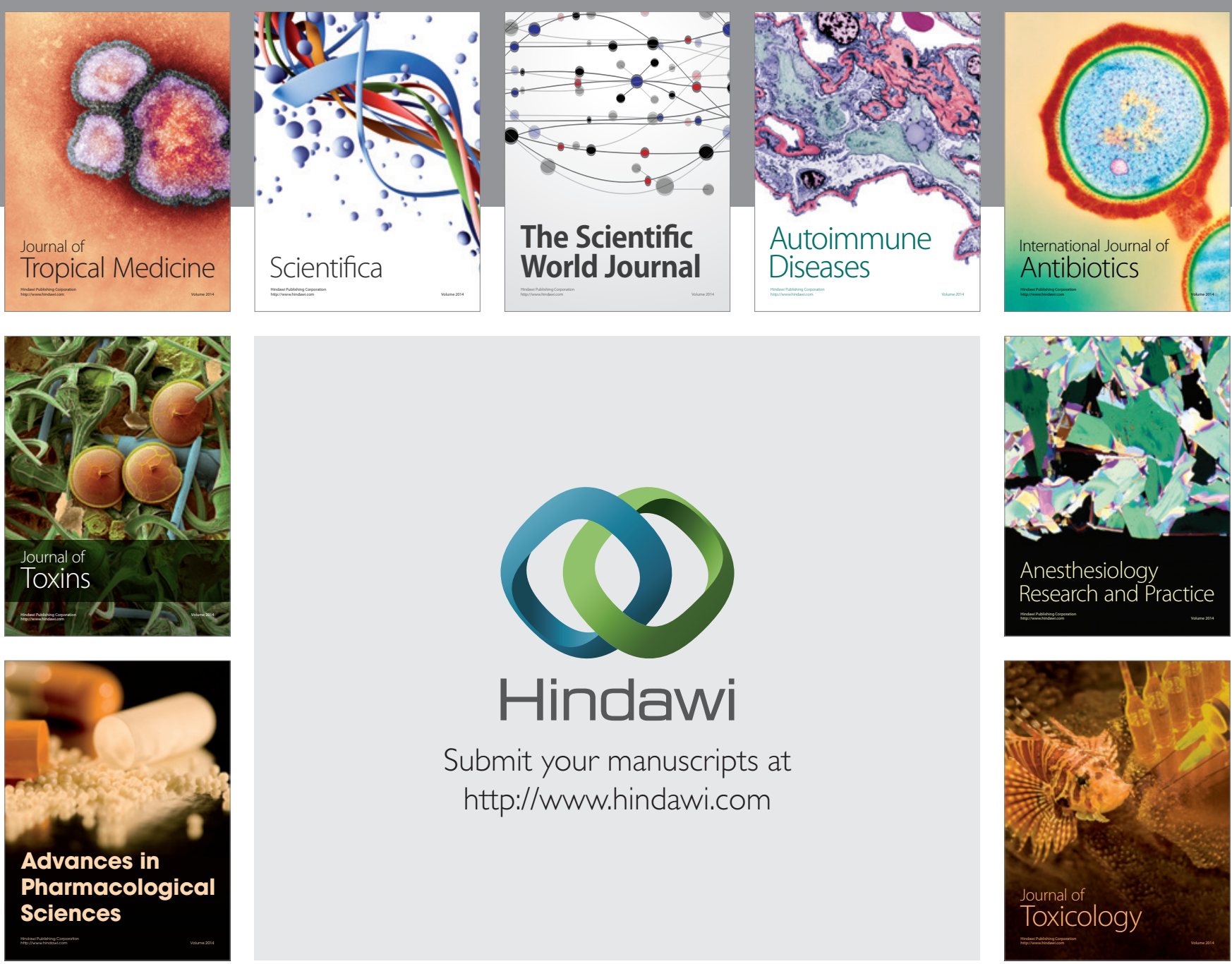

\section{Hindawi}

Submit your manuscripts at

http://www.hindawi.com
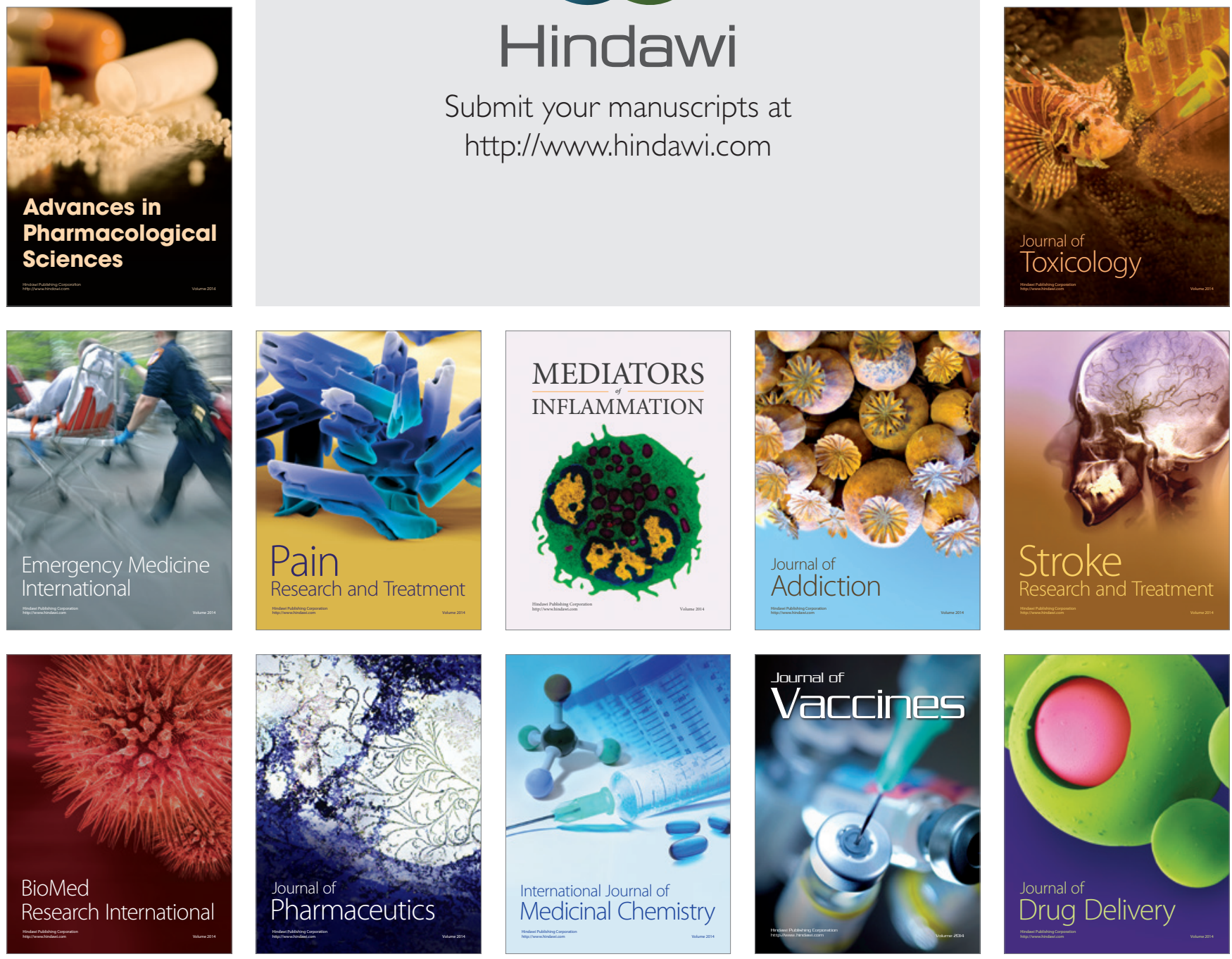